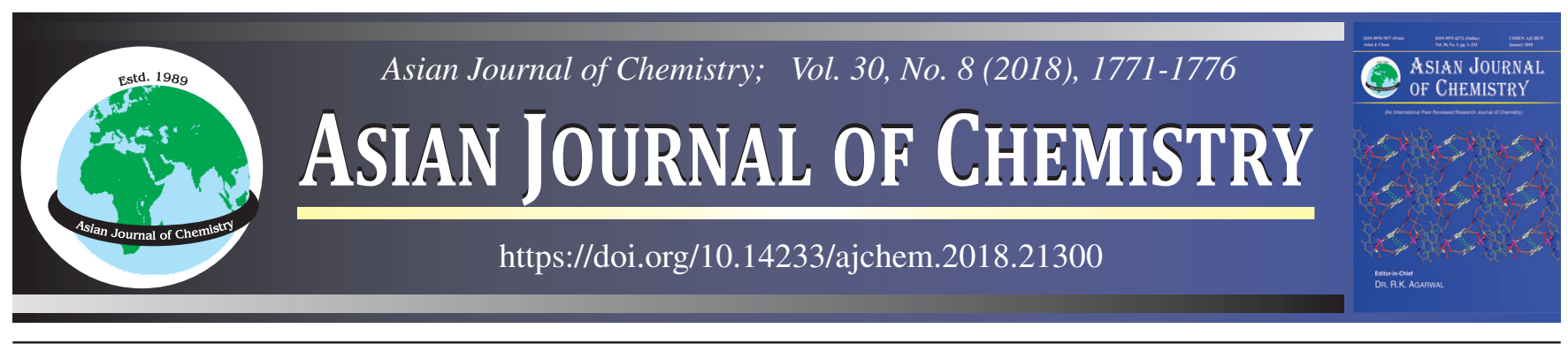

\title{
Evaluation of Suitability of Alumino-Silicate Precursor for Geopolymerization through Advance Analytical Techniques
}

\section{Sivasakthi ${ }^{1}$, R. Jeyalakshmi ${ }^{1,}$,, N.P. Rajamane ${ }^{2}$, J. Baskara Sundararaj ${ }^{2}$ and Rinu Jose ${ }^{2}$}

${ }^{1}$ Department of Chemistry, SRM University, Kattankulathur, Chennai-603 203, India

${ }^{2}$ Centre for Advanced Concrete Research, SRM University, Kattankulathur, Chennai-603 203, India

*Corresponding author: E-mail: rajyashree64@gmail.com

Received: 22 February 2018;

Accepted: 16 May 2018;

Published online: 30 June 2018;

AJC-18972

| The utilization of fly ash has become a tough task due to high landfill costs and interest in sustainable development. Geopolymer is an amorphous alumino silicate polymer can be used as binder in construction industries thereby the waste fly ash utilization in construction activities is possible. This study aims to evaluate the suitability of secondary source material fly ash for the geopolymerization reaction through analytical characterization to get geopolymer binder with reproducible quality. The analytical techniques such as XRF, XRD, SEM,

${ }^{29} \mathrm{Si}$ and ${ }^{27} \mathrm{Al}$ MAS-NMR spectroscopy and ATR FT-IR was used to characterize the precursors to get into the more in-depth understanding of | chemical, mineral composition, microstructure, Si and Al environment and alumino silicate bonding. An experimental result reveals that the fly ash was found to be active enough for the geopolymerization reaction. The mechanical strength of geopolymer was found to be in acceptable range and higher in case of $10 \mathrm{M}$ concentration. The ${ }^{29} \mathrm{Si}$ and ${ }^{27} \mathrm{Al}$ solid-state MAS-NMR spectroscopy of geopolymer represent the incorporation of aluminium into the silicate network structure of fly ash and the formation of network alumino silicate polymeric gel. The higher alkali concentration leads to the more sodium-alumino-silicate-hydrate (N-A-S-H) gel formation thereby increasing the strength properties.

Keywords: Geopolymer, Fly ash, ATR FT-IR, ${ }^{29}$ Si and ${ }^{27}$ Al MAS-NMR, XRD.

ᄂ _ - - - - - - - - - - - - - - - - - - - - - - - - - - - - -

\section{INTRODUCTION}

Fly ash is the industrial by-product obtained from the coal based thermal power plant, collected as the fine particles that are driven out of the boiler with the flue gases. The utilization of fly ash has become a main concern in modern years due to high landfill cost. The components of fly ash are depending upon the type of coal being burned, but the considerable amount of silicon dioxide (both amorphous and crystalline), aluminium oxide is present in all fly ash. The disposal of fly ash leftovers a foremost problem with only about $50-60 \%$ of the produced fly ash by the thermal power plant being consumed. In India, during the financial year 2013-14 around 173 million tonnes of fly ash was formed. The unutilized fly ash is dumped into ash bonds, which is not well designed and maintained. As per estimated statistics, the pollution of land, water and air happening by the dumping of fly ash of more than billion tonnes. In 2021-22, the thermal power plant aims to generate 300 million tonnes of fly ash per year and if that happens, the consumption of the fly ash being produced will be even difficult. Fly ash mainly contains $\mathrm{Al}_{2} \mathrm{O}_{3}$ and $\mathrm{SiO}_{2}$ as a significant composition; it can be efficiently used as a precursor for the preparation of alumino silicate polymer known as geopolymer.
Geopolymer can perform as a binder in a way similar or superior to the conventional binder portland cement. This geopolymer was found to be ecologically and environmentally friendly material because of the low energy consumption and lower $\mathrm{CO}_{2}$ emission during the production process. In contrast, the OPC binder requires high energy for the production emits a lot of $\mathrm{CO}_{2}$ gas during the production and consumes the natural sources, which are decreasing day by day. Inorganic alumino silicate polymer is an amorphous material having 2-3 D structure of empirical formula $\mathrm{M}_{\mathrm{n}}\left[-(\mathrm{Si}-\mathrm{O})_{\mathrm{z}}-\mathrm{Al}-\mathrm{O}\right]_{\mathrm{n}} \cdot \mathrm{wH}_{2} \mathrm{O}$, where $\mathrm{M}$ stands for alkaline cation $\mathrm{Na}^{+}$or $\mathrm{K}^{+}$[1-6]. Geopolymers can be prepared from the mixing precursors material such as mineral, or any by-product containing $\mathrm{SiO}_{2}$ and $\mathrm{Al}_{2} \mathrm{O}_{3}$ coming out of industries with a chemical reagent (alkaline activator solution) under the low-temperature condition below $100{ }^{\circ} \mathrm{C}$ which is known to had binding ability.

The main reason for the formation of stable geopolymer is the reaction between the aluminosilicate materials, which contains sufficient reactive $\mathrm{SiO}_{2}$ and $\mathrm{Al}_{2} \mathrm{O}_{3}$ content with the alkaline solution of high $\mathrm{pH}$. Alkali hydroxide $(\mathrm{NaOH} / \mathrm{KOH})$, Alkali silicate solutions $\left(\mathrm{Na}_{2} \mathrm{SiO}_{3} / \mathrm{K}_{2} \mathrm{SiO}_{3}\right)$ or a mixer of hydroxide and silicates can be used as an alkaline solution in geopolymer preparation process. When comparing the $\mathrm{NaOH}$ 
and $\mathrm{KOH}$, the potassium hydroxide shows a higher degree of alkalinity; conversely, the reported literature reveals that $\mathrm{NaOH}$ is having a better capacity to produce the individual molecules of silicates and aluminates (monomer) during the termination [7]. Geopolymer can become a replacement for ordinary cement binder having the properties such as gaining of $90 \%$ strength at 3 days, whereas portland cement requires 28 days to obtain, high resistance in an aggressive environment and fire tolerance; the specific properties are based upon the type of raw materials, proper mix design and curing regime.

The published papers dealt with geopolymer prepared from fly ash and metakaolin (MK) and combination with other industrial wastes such as ground granulated blast furnace slag (GGBS), rice husk ash (RHA) etc. They have studied the strength properties, durability studies and fire tolerance property, etc., [8-14]. Among the different source materials used in the geopolymer preparation, the fly ash based geo-polymer was found to give superior thermal resistance up to $800^{\circ} \mathrm{C}$ whereas other source materials does not. The main component, which is giving the binding action in the geopolymeric binder is sodium aluminium silicate hydrate. Meanwhile, the different oxide in a varied composition is present in precursor materials that lead to the formation of various alumino silicate hydrate formation also structurally disordered with thermally disrupted layer structure.

The geopolymerization reaction is yielding polymeric 3 dimensional structures consisting of -Si-O-Al-O- sialate bonds (amorphous alumino-silicate gel). This gel formation depends upon the capacity of aluminium ion $[\mathrm{Al}(\mathrm{VI})$ and $\mathrm{Al}(\mathrm{IV})]$ to persuade crystallographic changes and incorporation of $\mathrm{Al}(\mathrm{IV})$ in place of silicon in an alumino silicate framework.

For evaluating the reactivity of alumino silicate precursors, the ATR FT-IR spectroscopy and solid-state NMR studies was used in reported literature $[15,16]$. Fernandez Jimenez et al. [17] have studied the relationship among the different alumino silicates formed with the corresponding geopolymer binder strength. Type of alumino silicate precursor we have taken and potential variations in terms of reactivity and the activation energy required for reaction may influence the final geopolymer property. The most important reason for the variation in the performance of geopolymer formed from time to time may be the reactivity of the source material that is varying within the same source materials [11-14]. Therefore the characterization technique is required for quality control of precursor if geopolymers are to be applied alternative to portland cement with the same quality and the proper mix design is needed as cement has. This analysis links the characteristics of source material obtained from industry to the performance of final geopolymers prepared.

This paper aims to give insight on the precursor material (fly ash) characterization to know the suitability to undergo reaction and the performance of final geopolymer properties (with varying alkali concentration Ms 0.8 and 1.15) such as structural analysis and their mechanical properties.

\section{EXPERIMENTAL}

The low calcium class F fly ash was used as a precursor in this study, which is obtained from the coal based Thermal
Power Plant in Ennore, India. The fineness of fly ash is 330 $\mathrm{m}^{2} / \mathrm{kg}$ (Blaine). This fly ash was characterized directly without any processing. Alkali activator solution was prepared by mixing the sodium hydroxide $(50 \% \mathrm{NaOH})$ with the sodium silicate solution of molar ratio 2. The sodium silicate $\left(\mathrm{Na}_{2} \mathrm{SiO}_{3}\right)$ solution with $15 \% \mathrm{Na}_{2} \mathrm{O}, 33 \% \mathrm{SiO}_{2}$ and $52 \% \mathrm{H}_{2} \mathrm{O}$ was used in the mixture. The modulus $\mathrm{Ms}$ (molar ratio of $\mathrm{Na}_{2} \mathrm{O}$ to $\mathrm{SiO}_{2}$ ) of prepared liquid alkali activator is 0.8 and 1.15 and the final $\mathrm{SiO}_{2}, \mathrm{Na}_{2} \mathrm{O}, \mathrm{H}_{2} \mathrm{O}$ concentration and the molarity of a prepared solution is given in Table-1. After that, the alkali activator solution has to be kept for $24 \mathrm{~h}$ one-day prior use.

\begin{tabular}{|c|c|c|c|}
\hline \multicolumn{4}{|c|}{$\begin{array}{c}\text { TABLE-1 } \\
\text { CHEMICAL COMPOSITION OF ALKALINE } \\
\text { SOLUTIONS USED FOR THE PRESENT STUDY }\end{array}$} \\
\hline Wt (\%) & $\begin{array}{l}\mathrm{Na}_{2} \mathrm{SiO}_{3} \\
(\mathrm{Ms}: 2)\end{array}$ & $\begin{array}{c}\text { Final } \mathrm{Na}_{2} \mathrm{SiO}_{3} \\
\text { (Ms:1.15) }\end{array}$ & $\begin{array}{c}\text { Final } \mathrm{Na}_{2} \mathrm{SiO}_{3} \\
(\mathrm{Ms}: 1.15)\end{array}$ \\
\hline $\mathrm{SiO}_{2}$ & 15 & 12 & 21 \\
\hline $\mathrm{Na}_{2} \mathrm{O}$ & 30 & 13.75 & 18.25 \\
\hline $\mathrm{H}_{2} \mathrm{O}$ & 55 & 74.25 & 60.75 \\
\hline Ms (Silica modulus) & 2 & 0.87 & 1.15 \\
\hline Alkali conc. (Molarity) & - & 5 & 10 \\
\hline
\end{tabular}

Synthesis of geopolymer: The trials were conducted to optimize the procedure for the geopolymer synthesis. Sodium silicate solution with two different concentration 5 and $10 \mathrm{M}$ (modulus ratio 0.8 and 1.15) were used as an alkaline liquid solution and the corresponding geopolymer is named as FA1 and FA2 respectively. Geopolymer paste was prepared by mixing fly ash with an alkaline solution using Digi mortar mixer for $10 \mathrm{~min}$. The liquid added was $45 \%$ to the fly ash precursor. After complete mixing the specimens were cast into the cubical mould of $50 \mathrm{~mm}$, kept at room temperature for $24 \mathrm{~h}$ then heated at $80^{\circ} \mathrm{C}$ for $24 \mathrm{~h}$ in a laboratory grade oven to get the hardened sample for testing. For analytical characterization the crushed powder sample was used.

Testing and characterization methods: The morphology changes by scanning electron microscopy (SEM) was done using high-resolution field emission electron microscope model AEOS, 5600 Germany and the voltage used $24 \mathrm{kV}$. The ATR FT-IR was done for geopolymer paste on a Bruker IFS 66v/S FT-IR spectrometer the detector was DTGS and vertical ATR accessory. The OPUS software was used for performing the Data evaluation and spectra simulation from Bruker Optics. XRD patterns of powdered samples were collected on a PANalytical X'pert ${ }^{3}$ powder diffractometer with $\mathrm{Cu} \mathrm{K}_{\alpha}$ radiation generated at $40 \mathrm{~mA}$ and $45 \mathrm{kV}$. Samples were step scanned from $5^{\circ}$ to $70 \pm 0.01^{\circ} 2 \theta$ steps integrated at the rate of $2^{\circ}$ per $\mathrm{min}$. The XRD analysis was performed using the JCPDS ICDD data 2003 using PCPDFWIN software.

The Bruker solid-state ${ }^{29} \mathrm{Si}$ MAS-NMR of $79.46 \mathrm{MHz}$ was used and Bruker $7 \mathrm{~mm}$ probe, a $5 \mathrm{~mm}$ zirconia rotor and the spinning speed of $10.0 \mathrm{KHz}$. The standard used for ${ }^{29} \mathrm{Si} \mathrm{NMR}$ is tetra methyl silane (chemical shift $0 \mathrm{ppm}$ ). The solid-state ${ }^{27} \mathrm{Al}$ MAS-NMR spectra were collected at $156.320 \mathrm{MHz}$ using a $2.5 \mathrm{~mm}$ HX-CPMAS probe, a $2.5 \mathrm{~mm}$ low-Al zirconia rotor and a spinning speed of $22.0 \mathrm{kHz}$. The reference sample for ${ }^{27} \mathrm{Al}$ is aqueous $\mathrm{AlCl}_{3}$.

TGA/DTA was done by simultaneous thermal analysis (STA), NETSCH 2500 Regulus in the temperature range 30- 

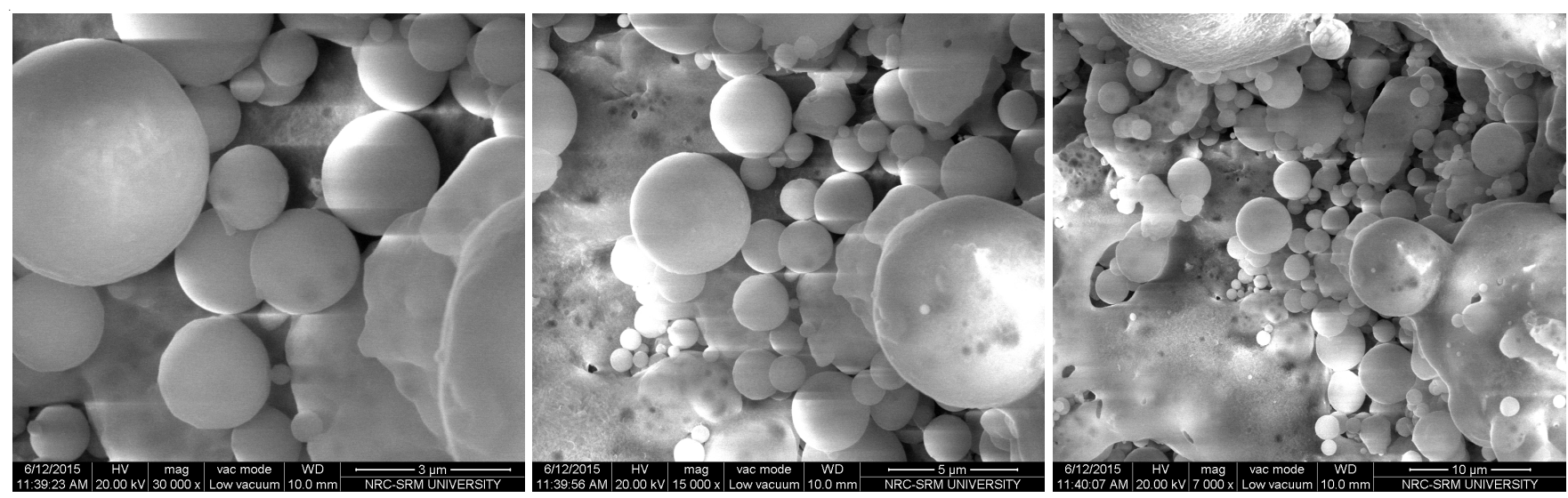

Fig. 1. SEM images of original fly ash

$1200{ }^{\circ} \mathrm{C}$ in floating air/nitrogen $(60 \mathrm{~mL} / \mathrm{min})$ with the heating rate of $10{ }^{\circ} \mathrm{C} / \mathrm{min}$.

The compressive strength measurement was performed using AIMIL compression testing machine for geopolymer paste with force applied at a rate of $2 \mathrm{KN} / \mathrm{s}$ at the age of 3, 7, 14 and 28 days. The results reported were the average of 5 replicates.

\section{RESULTS AND DISCUSSION}

\section{Characterization of fly ash}

Chemical and mineral composition: The chemical composition of fly ash was determined using energy dispersive Xray fluorescence spectroscopy (EDXRF) and the results are shown in Table- 2 . The fly ash contains nearly $80 \%$ of $\mathrm{SiO}_{2}$ and $\mathrm{Al}_{2} \mathrm{O}_{3}$ less than $5 \% \mathrm{CaO}$ and traces of other oxides in addition to $\mathrm{Fe}_{2} \mathrm{O}_{3}$. The $\mathrm{Si} / \mathrm{Al}$ ratio of fly ash is 4.2 . The fly ash satisfying the Class F according to the code IS 3812-1999.

\begin{tabular}{cccccccc}
\multicolumn{7}{c}{ TABLE-2 } \\
\multicolumn{7}{c}{ CHEMICAL COMPOSITION OF FLY } \\
ASH FROM EDXRF ANALYSIS \\
\hline $\begin{array}{c}\text { Chemical } \\
\text { composition }\end{array}$ & $\mathrm{CaO}$ & $\mathrm{SiO}_{2}$ & $\mathrm{Al}_{2} \mathrm{O}_{3}$ & $\mathrm{Na}_{2} \mathrm{O}$ & $\mathrm{K}_{2} \mathrm{O}$ & $\mathrm{MgO}$ & $\mathrm{Fe}_{2} \mathrm{O}_{3}$ \\
\hline$(\%)$ & 2.09 & 55 & 26 & 0.4 & 1.65 & 0.8 & 10.17 \\
\hline
\end{tabular}

SEM analysis: The SEM images of different magnification and EDAX of original fly ash are shown in Figs. 1 and 2 , respectively. The morphology of raw fly ash indicates that the fly ash particles are sphere-shaped. Vitreous particles of different sizes with deep spheres may hold some other particles also in their interiors. The EDAX of fly ash also represents the presence of higher amount of $\mathrm{Si}$ and $\mathrm{Al}$ element without any calcium.

\section{Characterization of fly ash and synthesized geopolymer}

FT-IR spectroscopy: Fig. 3 presents the FT-IR spectrum of fly ash. The fly ash shows the sharp band at $1093 \mathrm{~cm}^{-1}$ and a weak band near $908 \mathrm{~cm}^{-1}$ (high $\mathrm{Al}$ ) attributed to the asymmetric stretching of $\left(\mathrm{Si}, \mathrm{Al}^{\mathrm{IV}}\right)-\mathrm{O}-\mathrm{Si}$ in glass and asymmetric stretching of $\left(\mathrm{Si}, \mathrm{Al}^{\mathrm{IV}}\right)-\mathrm{O}-\mathrm{Si}$ in amorphous phases, respectively. Which is composed of higher $\mathrm{Al}$ concentration both bands are active in nature [18]. The weak band occurred at around 793 and $555 \mathrm{~cm}^{-1}$ corresponds to the symmetric stretching of Si-O-Si

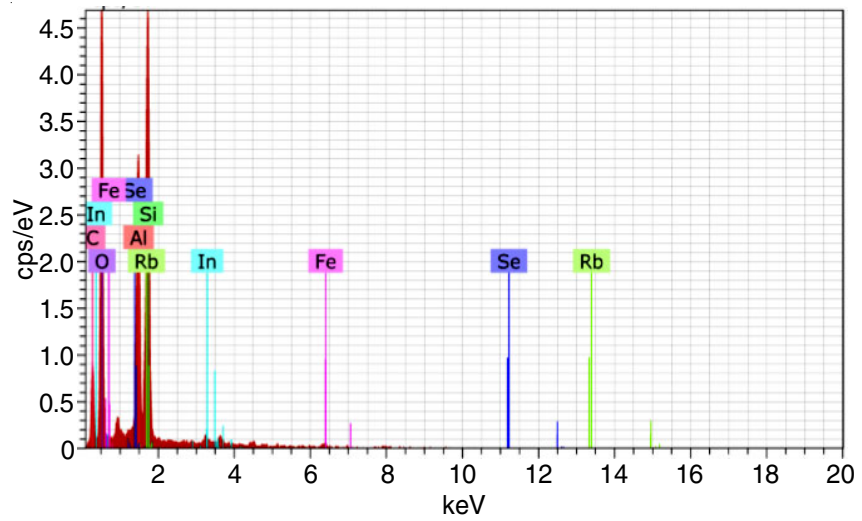

Fig. 2. EDAX of original fly ash

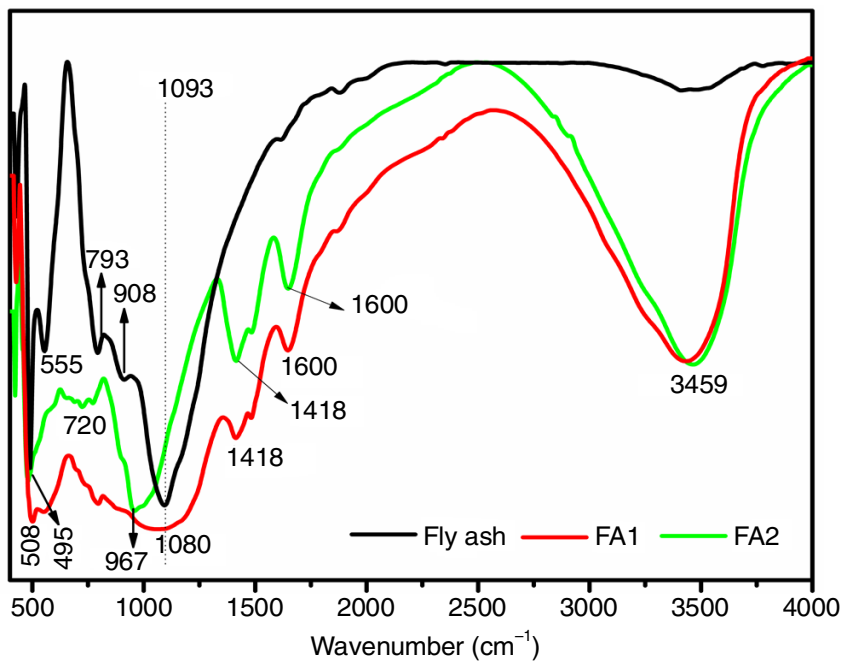

Fig. 3. FT-IR spectrum of original fly ash and their respective geopolymers FA1 and FA2

in quartz and stretching $\mathrm{Al}^{\mathrm{VI}}-\mathrm{O}$ of Mullite like structure both bands are inactive or less active for geopolymerization reaction. These active bonds are readily undergoing polymerization in alkaline condition by leaching out of $\mathrm{Si}$ and $\mathrm{Al}$ from fly ash.

Referring to the literature, the assignment of frequency observed in the samples can be explained. Around 1100-1000 $\mathrm{cm}^{-1}, \mathrm{~T}-\mathrm{O}(\mathrm{T}=\mathrm{Si} / \mathrm{Al})$ asymmetric stretching vibrations is considered to be the combination of $\mathrm{Si}-\mathrm{O}$ and $\mathrm{Al}-\mathrm{O}$ symmetric stretching. Shifting to lower wave number is an indicative of the formation Al-rich silicate gel during the activation of fly 
ash [19]. The more considerable shift in the vibration spectrum means greater intrusion of $\mathrm{Al}^{3+}$ into the $\left[\mathrm{SiO}_{4}\right]^{4}$. In the present case, the shift in frequency is observed from 1093to 1080 $\mathrm{cm}^{-1}$ for the geopolymer prepared with the Ms of $0.87(5 \mathrm{M})$ FA1 from the original fly ash and shifted to $967 \mathrm{~cm}^{-1}$ for FA2 (Ms $1.15,10 \mathrm{M})$. When increasing the alkali concentration the $\mathrm{Al}$ incorporation is greater ultimately the sodium alumino silicate hydrate gel (N-A-S-H) formation is also higher and binding action will be more. This observation coincides with the compressive strength results. The broad absorption band appeared after alkali reaction at around $3459 \mathrm{~cm}^{-1}$ is attributed to the -O-H stretching coming from the water present in alkali solution and $1600 \mathrm{~cm}^{-1}$ is due the $\mathrm{H}-\mathrm{O}-\mathrm{H}$ bending vibration this band does not appear in anhydrous fly ash. The band at $1440-1470 \mathrm{~cm}^{-1}$ could be assigned to the stretching bond of $\mathrm{O}-\mathrm{C}-\mathrm{O}$, it indicates the presence of sodium carbonate which is formed by the reaction of unreacted $\mathrm{Na}$ with the atmospheric $\mathrm{CO}_{2}$.

Solid state ${ }^{29} \mathrm{Si}$ and ${ }^{27} \mathrm{AI}$ MAS-NMR analysis: ${ }^{29} \mathrm{Si}$ MASNMR spectra of fly ash and geopolymer paste (FA1 and FA2) are presented in Fig. 4(a). The spectrum of the original fly ash has a broad signal in the range of -80 to $-108 \mathrm{ppm}$ indicates the heterogeneous distribution of silicon structural units and mainly associated with the resonance of initial glassy phase. The original fly ash showed peaks representing aluminium framework silicates, namely $\mathrm{Q}^{4}(-113 \mathrm{ppm}), \mathrm{Q}^{4}(1 \mathrm{Al})(-104.9 \mathrm{ppm}), \mathrm{Q}^{4}(2 \mathrm{Al})(-101.2$ $\mathrm{ppm}), \mathrm{Q}^{4}(3 \mathrm{Al})(-94 \mathrm{ppm})$ and $\mathrm{Q}^{4}(4 \mathrm{Al})(-88 \mathrm{ppm})$. After the alkali reaction incorporation of aluminium in the framework, silicate phases with average to high amounts are observed shifting of signals towards positive values indicate that the formation aluminium rich network. In other words, aluminium penetration in original silicate bone structure occurred during the alkali reaction by disrupting the bonds [20,21]. Also, the peaks for different $\mathrm{Q}^{\mathrm{n}}(\mathrm{mAl})$ are found to be more predominant and increasing intensity in both FA1 and FA2. However, the FA2 experiencing more shift with higher intensity represents the more $\mathrm{Al}$ intrusion and formation of more alumino silicate gel.

${ }^{27}$ Al MAS-NMR spectra of fly ash and geopolymer paste (FA1 and FA2) are presented in Fig. 4(b). The peak at around $60 \mathrm{ppm}$ is due to the presence of $\mathrm{Al}(\mathrm{IV})$ whereas chemical shift at $0 \mathrm{ppm}$, is due to the $\mathrm{Al}(\mathrm{VI})$. After alkali reaction, the peak intensity at $0 \mathrm{ppm}$ has decreased in FA1 and FA2 and some remnant $\mathrm{Al}(\mathrm{VI})$ is also observed in both cases however the unreacted $\mathrm{Al}(\mathrm{VI})$ is less in case of higher alkali concentration (FA2). The broad peak at $60.8 \mathrm{ppm}$ becomes narrower and slightly shifted towards the lower chemical shift of $59 \mathrm{ppm}$ in both cases. It implies that the formation of geopolymeric binder gel.

SEM analysis: SEM images of FA1 and FA2 showed in Fig. 5(a) and 5(b), respectively. The geopolymer was prepared under two condition were examined to know the extent of leaching process. The FA1 shows the gel formed over the spherical particle and the unreacted fly ash particles also exist. In FA2 the more gel was formed and overwhelmed the fly ash particles as seen in Fig. 5(b). Fewer unreacted particles are also observed. FA2 shows relatively more gel and dense alumina-silicate geopoly-mer proved that the reaction of fly ash increases with the alkali activator concentration increases.
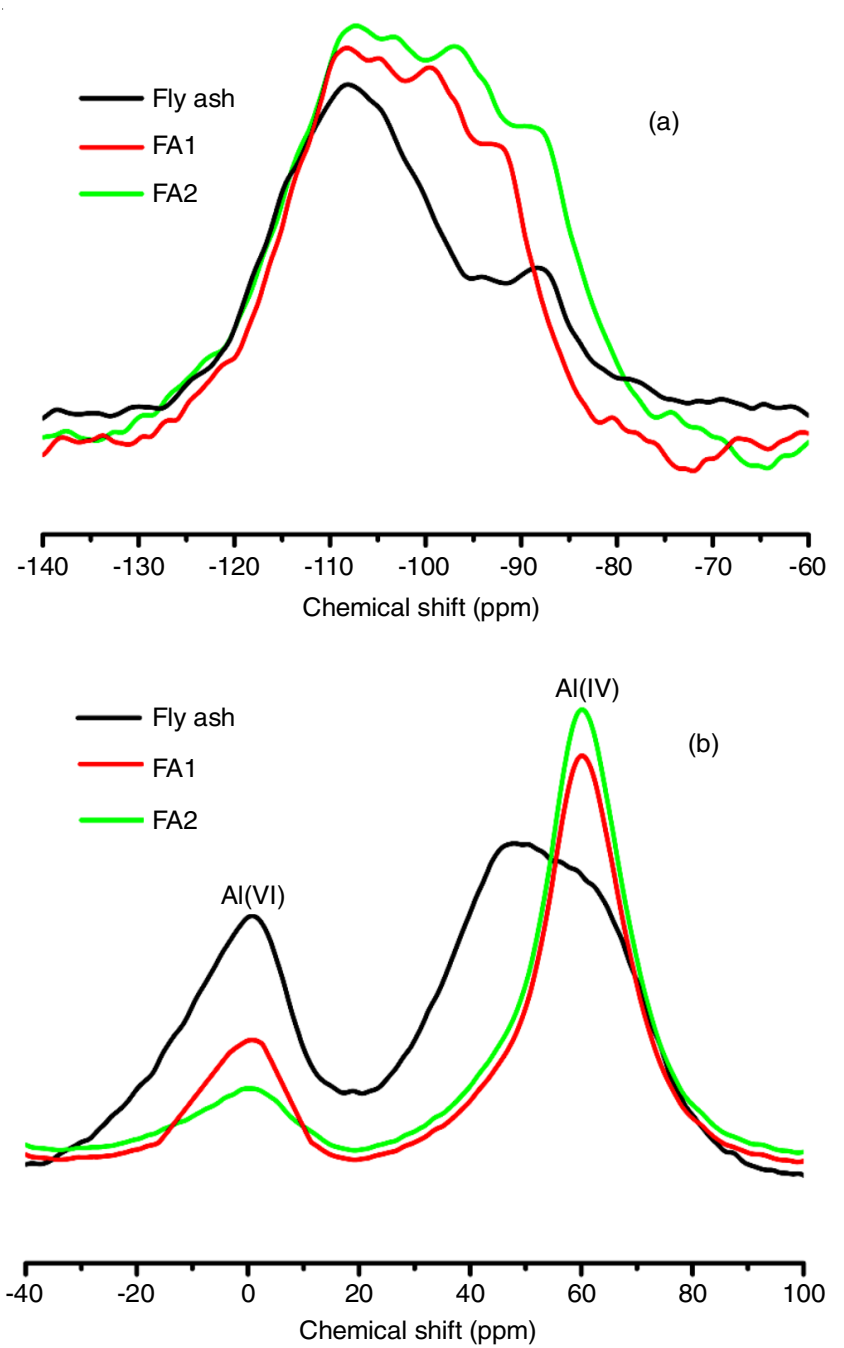

Fig. 4. MAS-NMR spectrum of original fly ash and their respective geopolymers FA1 and FA2 (a) ${ }^{29} \mathrm{Si}$ NMR (b) ${ }^{27} \mathrm{Al}$ NMR

XRD analysis: The fly ash contains the peaks which were assigned to Quartz $\left(\mathrm{SiO}_{2}\right.$, PDF \#00-046-1045) and Mullite $\left(\mathrm{Al}_{4.44} \mathrm{Si}_{1.56} \mathrm{O}_{9.78}, \mathrm{PDF} \# 01-074-4143\right)$ and these peaks represent the unreactive crystalline phases (Fig. 6). The fly ash is having the amorphous alumino silicate hump at approximately 22$30^{\circ} 2 \theta$. After the alkali reaction, the new peak appeared at $24^{\circ}$ $2 \theta$ value which corresponds to hydroxysodalite and nepheline in addition to the crystalline peaks of original fly ash (Fig. 6).

Mechanical strength: Fig. 7 shows the compressive strength results of geopolymer FA1 and FA2 at different curing ages. A comparison of the strength of FA1 and FA2, the geopolymer prepared with $10 \mathrm{M}(\mathrm{FA} 2, \mathrm{Ms}=1.15)$ showed the better behaviour at all curing ages studied compared to FA1 $(5 \mathrm{M}, \mathrm{Ms}=$ 0.87 ) and approximately $50 \%$ higher than the FA1. It was also observed that the increasing the reaction time also tends to progress the reaction thereby improving the compressive strength property. When comparing the curing ages from 3 days to 28 days the remarkable increase in strength was observed that is $350 \%$ and $160 \%$ in FA1 and FA2 respectively. From the FT-IR analysis and MAS-NMR studies, it was found that the higher alkali concentration (FA2-Ms 1.15 and $10 \mathrm{M}$ )) leads to the formation of more binding gel (N-A-S-H) by increasing the $\mathrm{Al}$ intrusion into the silicate backbone of original fly ash thereby increasing the strength properties too. 

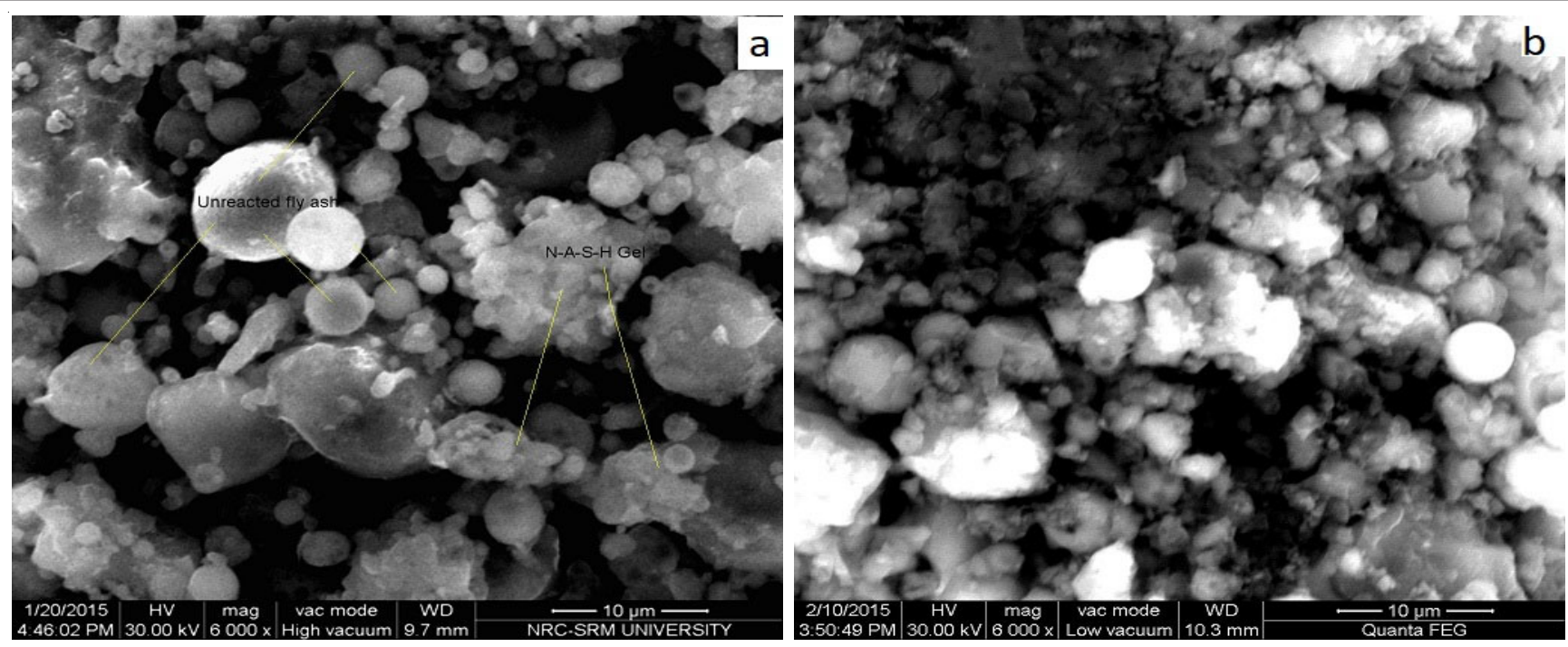

Fig. 5. SEM images of geopolymers FA1 and FA2

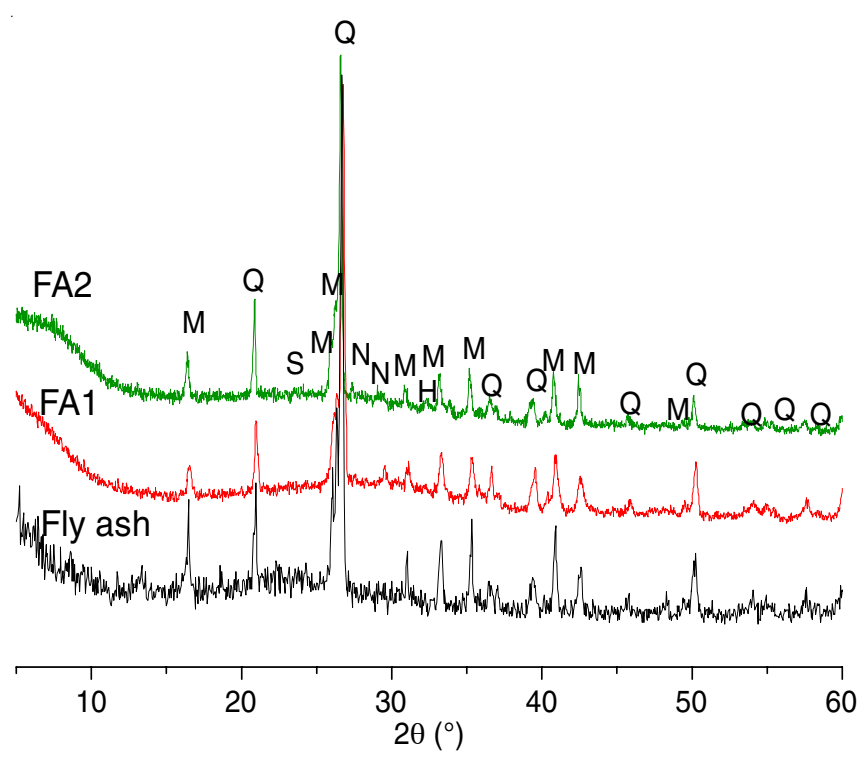

Fig. 6. XRD patterns of fly ash, FA1 and FA2

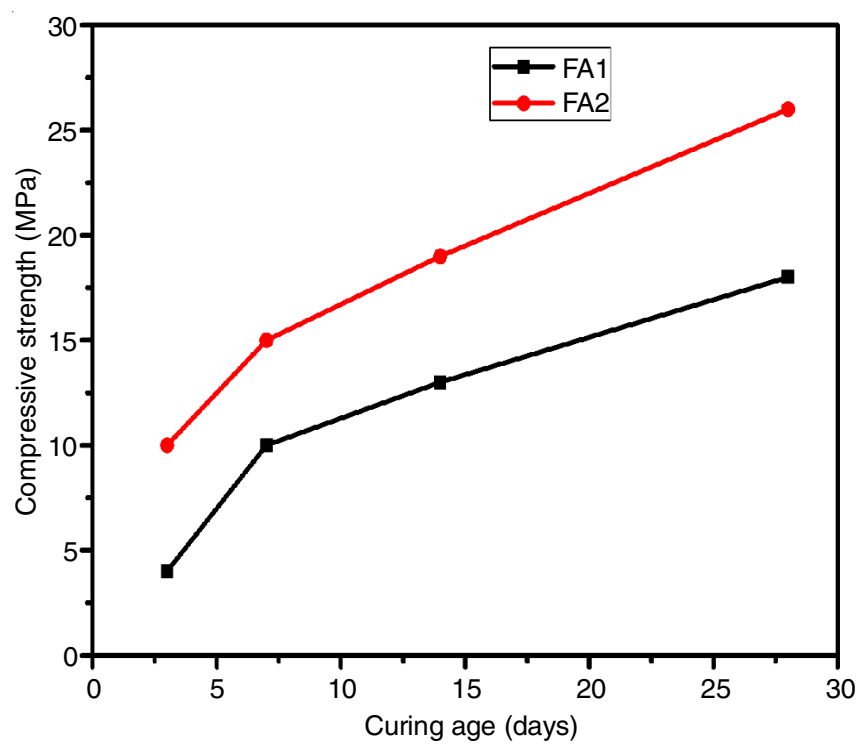

Fig. 7. Compressive strength of geopolymers FA1 and FA2 at different alkali concentration

\section{Conclusion}

This study is a part of the research on the development of high-temperature resistant geopolymer composites using $100 \%$ fly ash as a binder investigated the suitability of fly ash obtained from Ennore thermal power plant and the effect of alkali concen-tration and curing ages of alumino silicate gel paste. The extent of the reaction was examined through analytical techniques such as SEM, FT-IR, XRD and ${ }^{29} \mathrm{Si}$ and ${ }^{27} \mathrm{Al}$ MASNMR analysis. We also evaluated the mechanical strength at different curing ages with a diverse alkali solution.

- The SEM analysis of fly ash shows that the morphology of the fly ash is spherical in nature and forms more sodium alumino silicate gel in high alkaline condition (Ms 1.15) compared to lower silica modulus (Ms:0.87).

- The XRF analysis reveals that the fly ash contains more than $80 \%$ of $\mathrm{SiO}_{2}$ and $\mathrm{Al}_{2} \mathrm{O}_{3}$.

- The relationship between the compressive strength and alkali concentration performed using analytical techniques such as XRD solid-state NMR and FT-IR.

- The higher molarity (modulus $\mathrm{SiO}_{2} / \mathrm{Na}_{2} \mathrm{O} 1.15$ ) of alkaline solution appeared to provide higher compressive strength together with the considerable effect of curing period.

- The spectroscopic techniques FT-IR and MAS-NMR spectroscopy helped to understand the network structures of gels formed during the reaction. The FT-IR spectra of fly ash before and after alkali activation showed obvious changes in the active bonds of fly ash corresponding to $\mathrm{Si}-\mathrm{O}$ and $\mathrm{Al}-\mathrm{O}$ vibrational frequency. Displacement towards the lower values of frequency confirms the activation of fly ash particles during the reaction. From the ${ }^{29} \mathrm{Si}$ MAS-NMR spectral studies evident the penetration of $\mathrm{Al}$ atoms into the original polymeric silicate structure of the fly ash during activation reaction. The intrusion of $\mathrm{Al}$ into the $\mathrm{Si}-\mathrm{O}$ skeleton is more in case of high alkaline concentration observed through FT-IR and ${ }^{27} \mathrm{Al}$ MAS-NMR studies. It coincides with the compressive strength properties.

Hence advanced analytical techniques are considered to be valuable quality indicators in the preparation of geopolymers regarded as a future sustainable alternate binder. 


\section{ACKNOWLEDGEMENTS}

The authors acknowledge for the financial support from the Department of Science and Technology project under TDP grant no DST/TSG/STS/2012/20.

\section{REFERENCES}

1. J.L. Provis, A. Palomo and C. Shi, Cement Concr. Res., 78, 110 (2015); https://doi.org/10.1016/j.cemconres.2015.04.013.

2. J.L. Provis and J.S.J. van Deventer, In Proceeding of Alkali-Activated Materials: State-of-the-Art Report, RILEMTC 224-AAM, Springer/ RILEM, Dordrecht(2014).

3. C. Shi and J. Qian, Resour. Conserv. Recycling, 29, 195 (2000); https://doi.org/10.1016/S0921-3449(99)00060-9.

4. C. Shi, A.F. Jiménez and A. Palomo, Cement Concr. Res., 41, 750 (2011); https://doi.org/10.1016/j.cemconres.2011.03.016.

5. S.D. Wang, X.C. Pu, K.L. Scrivener and P.L. Pratt, Adv. Cement Res., 7, 93 (1995); https://doi.org/10.1680/adcr.1995.7.27.93.

6. J. Davidovits, Geopolymer Chemistry and Applications, Institut Géopolymère, Saint-Quentin, France, p. 28 (2008).

7. P. Duxson, A. Fernández-Jiménez, J.L. Provis, G.C. Lukey, A. Palomo and J.S.J. van Deventer, J. Mater. Sci., 42, 2917 (2007); https://doi.org/10.1007/s10853-006-0637-z.

8. D.L.Y. Kong, J.G. Sanjayan and K. Sagoe-Crentsil, Cement Concr. Res., 37, 1583 (2007);

https://doi.org/10.1016/j.cemconres.2007.08.021.

9. S. Donatello, C. Kuenzel, A. Palomo and A. Fernández-Jiménez, Cement Concr. Compos., 45, 234 (2014);

https://doi.org/10.1016/i.cemconcomp.2013.09.010.
10. T. Bakharev, Cement Concr. Res., 36, 1134 (2006); https://doi.org/10.1016/j.cemconres.2006.03.022.

11. A.M. Rashad and S.R. Zeedan, Constr. Build. Mater, 25, 3098 (2011); https://doi.org/10.1016/j.conbuildmat.2010.12.044.

12. S.A. Bernal, R.M. de Gutiérrez and J.L. Provis, Constr. Build. Mater, 33, 99 (2012); https://doi.org/10.1016/j.conbuildmat.2012.01.017.

13. C. Li, H. Sun and L. Li, Cement Concr. Res., 40, 1341 (2010); https://doi.org/10.1016/j.cemconres.2010.03.020.

14. S.M. Park, J.G. Jang, N.K. Lee and H.K. Lee, Cement Concr. Res., 89, 72 (2016); https://doi.org/10.1016/j.cemconres.2016.08.004.

15. V.F.F. Barbosa, K.J.D. MacKenzie and C. Thaumaturgo, Int. J. Inorg. Mater, 2, 309 (2000); https://doi.org/10.1016/S1466-6049(00)00041-6.

16. J.L. Provis, P. Duxson, G.C. Lukey and J.S.J. van Deventer, Chem. Mater, 17, 2976 (2005); https://doi.org/10.1021/cm050219i.

17. A. Ferna'ndez-Jimenez, A. Palomo, I. Sobrados and J. Sanz, Micropor. Mesopor. Mater, 91, 111 (2006); https://doi.org/10.1016/j.micromeso.2005.11.015.

18. Z. Zhang, H. Wang and J.L. Provis, J. Sustain. Cement-Based Mater. 1, 154 (2012); https://doi.org/10.1080/21650373.2012.752620.

19. K. Zheng, L. Chen and M. Gbozee, Constr. Build. Mater., 125, 1114 (2016); https://doi.org/10.1016/j.conbuildmat.2016.09.007.

20. A. Fernández-Jiménez and A. Palomo, Fuel, 82, 2259 (2003); https://doi.org/10.1016/S0016-2361(03)00194-7.

21. I. Catanescu, M. Georgescu and A. Melinescu, UPB Sci. Bull., 74, 1 (2012) 